\title{
Randomised controlled comparative study of methyldopa and oxprenolol in treatment of hypertension in pregnancy
}

\author{
JACK FIDLER， VALERIE SMITH， PETER FAYERS， MICHAEL DE SWIET
}

\begin{abstract}
One hundred pregnant women with hypertension (defined as diastolic blood pressure at or above $95 \mathrm{~mm}$ $\mathrm{Hg}$ ) were allocated at random to treatment with methyldopa or oxprenolol and were compared with nonhypertensive controls matched according to parity and gestation at delivery. The patients were also stratified into those entering the study early (before 32 weeks' gestation) and those entering late (after 32 weeks' gestation). Although there were no differences in diastolic blood pressure between the hypertensive groups before or during treatment, in the early entry group the systolic blood pressure at entry of those allocated to oxprenolol was significantly higher than that of those receiving methyldopa; this difference remained throughout the treatment period. Also in the early entry group further increments of drug treatment were required to control blood pressure of patients receiving oxprenolol than in those receiving methyldopa.

The eventual fetal outcome for all patients treated with methyldopa was the same as that for those treated with oxprenolol; birth weight, placental weight, head circumference, and Apgar score were not significantly different and there were no stillbirths in either group.
\end{abstract}

\footnotetext{
Institute of Obstetrics and Gynaecology, Queen Charlotte's Maternity Hospital, London W6 OXG

JACK FIDLER, FRACP, MRCOG, honorary lecturer

VALERIE SMITH, SRN, MTD, research midwife

MICHAEL DE SWIET, MD, FRCP, consultant physician

Medical Research Council, Tuberculosis and Chest Diseases Unit, Brompton Hospital, London SW3 6HP

PETER FAYERS, BSC, statistician

Correspondence to: Dr Michael de Swiet.
}

\section{Introduction}

Methyldopa is the drug most commonly used by obstetricians for the treatment of hypertension in pregnancy. ${ }^{1}$ Beta adrenergic blocking drugs are often used in non-pregnant subjects with hypertension, but there has been concern about their use in pregnancy. ${ }^{2}$ Rubin et al, however, showed that atenolol was superior to placebo in the treatment of hypertension in pregnancy. ${ }^{3}$ Gallery et al compared methyldopa and oxprenolol and suggested that oxprenolol offered a specific advantage over methyldopa as pregnant women treated with oxprenolol were delivered of infants of greater birth weight. ${ }^{4}$ In an attempt to confirm this important finding we repeated the study in a larger series and also examined normotensive controls.

\section{Patients and methods}

All the women booked for delivery at Queen Charlotte's Maternity Hospital who had diastolic blood pressure of at least $95 \mathrm{~mm} \mathrm{Hg}$ on two separate occasions at least 24 hours apart or greater than $105 \mathrm{~mm} \mathrm{Hg}$ on one occasion were classified as hypertensive and entered into the study. A research nurse measured blood pressure using a random zero sphygmomanometer ${ }^{5}$; Korotkoff phase IV (muffling) was taken as diastolic blood pressure. The pressure was measured in the right arm after the patient had rested sitting for five minutes.

No patients had asthma, heart failure, or heart block. Eleven patients who satisfied the entry criteria were excluded: six were taking other hypertensive medication, two had diabetes, one was expecting twins, one had renal disease, and one had congenital adrenal hyperplasia. The remaining 100 patients were allocated at random to receive either methyldopa or oxprenolol. To ensure homogeneity between the two treatment groups the randomisation was stratified into five gestational groups at entry: less than 20 weeks, 20 to 28 weeks, 29 to 32 weeks, 33 to 36 weeks, and more than 36 weeks. Although we analysed the data allowing for this stratification, the total number of patients entering the study at less than 32 weeks' gestation was small. For this reason and for simplicity of presentation and comparison with other studies the data were pooled and the groups divided into two subgroups: those entering the study at less than or equal to 32 weeks' gestation (early entry group) and those entering at more than 32 weeks' gestation (late entry group).

Informed consent was obtained from patients before entry into the study. 
A normotensive control-that is, a patient whose blood pressure was recorded in hospital notes as less than $90 \mathrm{~mm} \mathrm{Hg}$ throughout pregnancy-was selected for each study patient. The woman with the nearest hospital reference number after that of the index patient, matched for parity and gestational age at delivery, was chosen as the control. Appropriate controls could not be found for two patients because of their high parity and low gestational age at delivery: these patients were excluded from comparison of study patients and controls.

All outpatients were seen every two weeks until 36 weeks' gestation and thereafter every week until delivery. Patients tested their own urine at home every day. Urine analysis was performed and serum uric acid measured at every outpatient visit. Patients were admitted to hospital if their blood pressure exceeded $110 \mathrm{~mm} \mathrm{Hg}$ diastolic, if there was albuminuria (more than a trace by Albustix), or for obstetric reasons. All inpatients were assessed by the medical team every one or two days; urine analysis was performed daily, and uric acid was measured weekly. Cardiotocography was performed on all patients at admission and repeated at least twice weekly. For the purposes of this study an abnormal cardiotocogram was one where there was $(a)$ an episode of tachycardia (fetal heart rate of more than 160 beats $/ \mathrm{min}$ ) lasting more than five minutes; $(b)$ an episode of bradycardia (fetal heart rate of less than 120 beats/min) lasting more than five minutes; (c) "flattening" of the tracing (lack of variability of fetal heart rate to within five beats/min for more than five minutes); or $(d)$ late deceleration (occurring more than 15 seconds from the peak of contraction).

The initial doses of the drugs were $250 \mathrm{mg}$ methyldopa three times a day or $80 \mathrm{mg}$ oxprenolol twice a day. The target diastolic blood pressure was less than $95 \mathrm{~mm} \mathrm{Hg}$. If this was not reached after two weeks' treatment as an outpatient or $\mathbf{4 8}$ hours' treatment as an inpatient the dose was doubled and then doubled again after a similar period if necessary. If the target blood pressure was not reached at a dose of $3 \mathrm{~g}$ methyldopa a day or $640 \mathrm{mg}$ oxprenolol a day, hydralazine $25 \mathrm{mg}$ three times a day was added to the regimen, increasing to $50 \mathrm{mg}$ and $100 \mathrm{mg}$ three times a day if necessary.

All study patients who did not go into spontaneous labour before term had labour induced with $5 \mathrm{mg}$ pessaries of prostaglandin $\mathrm{E}_{2}$, provided that there was no contraindication to vaginal delivery.

The birth weight was adjusted for maternal height and weight at mid-pregnancy, according to the data of Thomson et al ${ }^{6}$ These data were also used to convert the adjusted birth weight to a percentage of normal weight and to obtain a standard deviation score, corrected for parity and gestation.?

Continuous measurements such as blood pressure and weight were compared using a two tail $t$ test. The controls were matched with treated patients and paired $t$ tests were used for these comparisons.
Categorical data such as numbers of abnormal versus normal were tested using $\chi^{2}$ test with allowance for paired data as appropriate. All continuous variables were expressed as means (SD).

\section{Results}

Two patients, one receiving methyldopa and the other oxprenolol, $\mathbb{D}$ were delivered at other hospitals. As complete data were not available for these patients no controls were selected for them. Where data are 0 incomplete this is indicated in the tables.

Table I shows the characteristics of the patients at entry. There were no significant differences between the groups in age, number of primigravidas, or gestational age. The weight of the early entry group at entry was significantly greater $(p<0.05)$ than that of the late entry group, possibly reflecting a greater likelihood of pregnancy associated hypertension in the early entry group. The weight of controls at entry was lower than that of study patients.

Table II gives details of blood pressure. As expected, the systolic 0 and diastolic blood pressure of the controls at entry was lower than $\vec{O}$ that of the study patients. The systolic blood pressure of those in the $\overrightarrow{\vec{\omega}}$ early entry group receiving oxprenolol was a mean of $5 \mathrm{~mm} \mathrm{Hg}$ higher than that of those in the same group receiving methyldopa $(\mathrm{p}<0.05)$. $\frac{O}{\partial}$ This difference was not found in the diastolic blood pressure. Table II 3 also compares the blood pressure at entry, the mean of all blood pressures recorded for each patient receiving treatment, the maximum $\mathscr{O}_{\infty}$ recorded while receiving treatment, and the last recorded before labour or elective caesarean section. In all treated groups the mean and last $\mathscr{C}$ recorded systolic and diastolic blood pressures were lower than those ? recorded at entry.

Table III shows the maximum daily dose of methyldopa or $N$ oxprenolol given with or without hydralazine. The only significant difference was in the early entry group where one quarter of those receiving oxprenolol required hydralazine to control blood pressure $\vec{\infty}$ $(\mathrm{p}<0.05)$

Table IV gives the characteristics of pregnancy of treated patients. There were no significant differences between the treatment groups in the number of patients admitted to hospital for hypertension, the $\vec{\varphi}$ median number of days spent in hospital for hypertension, the prevalence of abnormal antenatal cardiotocograms, the prevalence and degree of albuminuria, or the concentrations of serum uric acid.

Table $\mathrm{V}$ shows the fetal outcome and perinatal characteristics for each group. There was no significant difference in gestation at delivery. Two patients (one in each treatment group) had abortions, and two control patients had stillbirths (sirenomelia at 33 weeks and cardiopul-

TABLE I-Characteristics at entry of patients treated with methyldopa and oxprenolol by gestation at entry and of controls. Results are means (SD)

\begin{tabular}{|c|c|c|c|c|c|c|c|c|c|}
\hline & \multicolumn{3}{|c|}{ Early entry group* } & \multicolumn{3}{|c|}{ Late entry group* } & \multicolumn{3}{|c|}{ All patients } \\
\hline & $\begin{array}{l}\text { Methyldopa } \\
(\mathrm{n}=22)\end{array}$ & $\begin{array}{c}\text { Oxprenolol } \\
(n=24)\end{array}$ & $\begin{array}{l}\text { Controls } \\
(n=42)\end{array}$ & $\begin{array}{l}\text { Methyldopa } \\
(\mathrm{n}=28)\end{array}$ & $\underset{(n=26)}{\text { Oxprenolol }}$ & $\begin{array}{l}\text { Controls } \\
(n=54)\end{array}$ & $\begin{array}{l}\text { Methyldopa } \\
(\mathrm{n}=50)\end{array}$ & $\underset{(n=50)}{\text { Oxprenolol }}$ & $\begin{array}{l}\text { Controls } \\
(n=96)\end{array}$ \\
\hline $\begin{array}{l}\text { Age of patients (years) } \\
\text { No of primigravidas } \\
\text { Gestation (weeks) } \\
\text { Maternal weight at } 20 \text { weeks (kg) } \\
\text { No of smokers }\end{array}$ & $\begin{array}{c}29(6) \\
14 \\
23 \cdot 9(6 \cdot 7) \\
72(20) \\
3\end{array}$ & $\begin{array}{c}31(6) \\
17 \\
22 \cdot 5(7 \cdot 2) \\
71(18) \\
8\end{array}$ & $\begin{array}{c}28(6) \\
31 \\
23 \cdot 2(6 \cdot 9) \\
62(7) \\
11\end{array}$ & $\begin{array}{c}28(6) \\
12 \\
36 \cdot 0(1 \cdot 1) \\
68(14) \\
5\end{array}$ & $\begin{array}{c}29(5) \\
17 \\
36 \cdot 3(1 \cdot 7) \\
66(11) \\
3\end{array}$ & $\begin{array}{c}28(5) \\
29 \\
36 \cdot 1(1 \cdot 6) \\
62(8) \\
11\end{array}$ & $\begin{array}{c}29(6) \\
26 \\
30 \cdot 9(7 \cdot 5) \\
69(17) \\
8\end{array}$ & $\begin{array}{c}30(6) \\
34 \\
29 \cdot 9(8 \cdot 5) \\
68(15) \\
11\end{array}$ & $\begin{array}{c}28(6) \\
60 \\
30 \cdot 5(7 \cdot 9) \\
62(8) \\
22\end{array}$ \\
\hline
\end{tabular}

* Early entry = less than or equal to 32 weeks' gestation; late entry = more than 32 weeks' gestation.

TABLE II-Blood pressure in patients treated with methyldopa and oxprenolol and in controls by gestation at entry. Results are means (SD)

\begin{tabular}{|c|c|c|c|c|c|c|c|c|c|}
\hline & \multicolumn{3}{|c|}{ Early entry group* } & \multicolumn{3}{|c|}{ Late entry group* } & \multicolumn{3}{|c|}{ All patients } \\
\hline & $\begin{array}{c}\text { Methyldopa } \\
(\mathrm{n}=22)\end{array}$ & $\underset{(\mathrm{n}=24)}{\text { Oxprenolol }}$ & $\begin{array}{c}\text { Controls } \\
(n=42)\end{array}$ & $\begin{array}{l}\text { Methyldopa } \\
(\mathrm{n}=28)\end{array}$ & $\begin{array}{c}\text { Oxprenolol } \\
(\mathrm{n}=26)\end{array}$ & $\begin{array}{c}\text { Controls } \\
(n=54)\end{array}$ & $\begin{array}{c}\text { Methyldopa } \\
(\mathrm{n}=50)\end{array}$ & $\begin{array}{c}\text { Oxprenolol } \\
(n=50)\end{array}$ & $\begin{array}{l}\text { Controls } \\
(n=96)\end{array}$ \\
\hline $\begin{array}{l}\text { Systolic: } \\
\text { At entry } \\
\text { Mean of all readings } \S \\
\text { Maximum during treatment } \S \\
\text { Last before labour or elective }\end{array}$ & $\begin{array}{l}146(9) \dagger \\
134(10) \\
149(9)\end{array}$ & $\begin{array}{l}151(9) \dagger \\
138(10) \\
153(12)\end{array}$ & $\begin{array}{l}117(12) \ddagger \\
117(8) \ddagger \\
122(11) \ddagger\end{array}$ & $\begin{array}{l}142(9) \dagger \\
135(10) \\
147(10)\end{array}$ & $\begin{array}{l}143(11) \dagger \\
137(8) \\
148(11)\end{array}$ & $\begin{array}{l}122(12)_{\ddagger}^{+} \\
118(10) \ddagger \\
123(11)_{+}^{\ddagger}\end{array}$ & $\begin{array}{l}143(9) \dagger \\
135(10) \\
148(9)\end{array}$ & $\begin{array}{l}147(11) \dagger \\
137(9) \\
151(11)\end{array}$ & $\begin{array}{l}120(12) \ddagger \\
118(9) \ddagger \\
122(11) \ddagger\end{array}$ \\
\hline caesarean section $\S$ & $129(16)$ & $136(12)$ & $118(11) \ddagger$ & $135(13)$ & $135(12)$ & $120(9) \ddagger$ & $132(14)$ & $135(11)$ & $119(10) \pm$ \\
\hline $\begin{array}{l}\text { At entry } \\
\text { Mean of all readings } \S \\
\text { Maximum during treatment } \S\end{array}$ & $\begin{array}{l}99(3) \dagger \\
89(7) \\
100(4)\end{array}$ & $\begin{array}{l}99(4) \dagger \\
88(8) \\
100(5)\end{array}$ & $\begin{array}{l}68(6) \ddagger \\
71(5) \ddagger \\
75(7) \ddagger\end{array}$ & $\begin{array}{l}98(3) \dagger \\
91(6) \\
101(5)\end{array}$ & $\begin{array}{l}100(4) \dagger \\
92(4) \\
101(5)\end{array}$ & $\begin{array}{l}72(8)+ \\
73(6) \ddagger \\
75(7) \stackrel{+}{\ddagger}\end{array}$ & $\begin{array}{l}98(3) \dagger \\
90(7) \\
100(5)\end{array}$ & $\begin{array}{l}100(4)+ \\
90(7) \\
101(5)\end{array}$ & $\begin{array}{l}71(7) \ddagger \\
72(6) \ddagger \\
75(7) \ddagger\end{array}$ \\
\hline $\begin{array}{l}\text { Last before labour or elective } \\
\text { caesarean section } \S\end{array}$ & $84(13)$ & $87(13)$ & $72(8)_{+}^{+}$ & $92(10)$ & $90(8)$ & $74(9)_{\leftarrow}^{+}$ & $88(12)$ & $89(11)$ & $73(8)_{\ddagger}^{+}$ \\
\hline
\end{tabular}

* Early entry = less than or equal to 32 weeks' gestation; late entry = more than 32 weeks' gestation.

$\dagger$ Entry blood pressure greater than mean and last blood pressure within group (p-0.05).

$\ddagger$ Blood pressure of controls less than treated patients ( $p<0 \cdot 01$ )

$\$$ Data incomplete: two patients delivered at other hospitals and two patients aborted. 
monary hypoplasia at 36 weeks). The remaining 98 babies of patients treated for hypertension were normal on discharge from hospital. Comparison of treatment groups showed no significant difference in the rates of spontaneous delivery, induction, or caesarean section. There was no difference in the mean placental weights, adjusted birth weight, centile birth weight, or standardisation score of birth weight between treatment groups or between early and late entry groups. Furthermore, there were no significant differences in these indices of birth weight between treatment and control groups. There was no significant difference between the groups in mean head circumference. In addition, when treatment was started between 16 and 20 weeks' gestation, the head circumference at birth of five neonates exposed to methyldopa $(35.4 \pm 2.3 \mathrm{~cm})$ was not significantly different from that of six neonates exposed to oxprenolol $(33.2+2.0 \mathrm{~cm})$ or from that of the babies of the corresponding 11 matched controls $(34.4 \pm 2.4 \mathrm{~cm})$.

In the early entry group there were more abnormal intrapartum cardiotocograms (see methods section) in patients treated with oxprenolol $(12(54 \%))$ than in those treated with methyldopa (four $(18 \%))$ and all controls (nine $(21 \%))(p<0.05)$. Bradycardia was the most common abnormality. At least $95 \%$ of all babies had Apgar scores from 7 to 10 at five minutes. In the late entry group there was no difference between those treated with oxprenolol and those treated with methyldopa in the prevalence of abnormal cardiotocograms or of bradycardia.

\section{Discussion}

In a similar study to ours and using identical entry criteria Gallery et al reported a mean difference of about $400 \mathrm{~g}$ in birth weight and $60 \mathrm{~g}$ in placental weight in favour of 26 patients treated with oxprenolol, compared with 27 treated with methyldopa. ${ }^{4}$ Our results do not support these findings. Indeed, we found that the mean birth weight of the babies of mothers treated with methyldopa was $89 \mathrm{~g}$ more than that of babies of mothers treated with oxprenolol, but this difference was not significant. The difference between our study and that of Gallery et al may be due to the fact that the number of patients

TABLE III-Maximum daily dose of methyldopa and oxprenolol given to achieve control of blood pressure by gestation at entry* $\dagger$ Figures are number of patients

\begin{tabular}{|c|c|c|c|c|c|c|}
\hline & \multicolumn{2}{|c|}{ Early entry $\ddagger$} & \multicolumn{2}{|c|}{ Late entry $\ddagger$} & \multicolumn{2}{|c|}{ All patients } \\
\hline & $\begin{array}{l}\text { Methyldopa } \\
(n=20)\end{array}$ & $\begin{array}{c}\text { Oxprenolol } \\
(n=22)\end{array}$ & $\begin{array}{l}\text { Methyldopa } \\
(n=28)\end{array}$ & $\begin{array}{c}\text { Oxprenolol } \\
(n=26)\end{array}$ & $\begin{array}{l}\text { Methyldopa } \\
(n=48)\end{array}$ & $\begin{array}{c}\text { Oxprenolol } \\
(\mathbf{n}=48)\end{array}$ \\
\hline $\begin{array}{l}\text { Initial dose }(750 \mathrm{mg} / 160 \mathrm{mg}) \S \\
\text { Doubled }(1500 \mathrm{mg} / 320 \mathrm{mg}) \S \\
\text { Redoubled }(3000 \mathrm{mg} / 640 \mathrm{mg}) \S \\
\text { With hydralazine }(3000 \mathrm{mg} / 640 \mathrm{mg} \text { and hydralazine })\end{array}$ & $\begin{array}{r}10 \\
8 \\
2 \\
0\end{array}$ & $\begin{array}{r}13 \\
1 \\
3 \\
5\end{array}$ & $\begin{array}{r}18 \\
6 \\
2 \\
2\end{array}$ & $\begin{array}{r}14 \\
6 \\
5 \\
1\end{array}$ & $\begin{array}{r}28 \\
14 \\
4 \\
2\end{array}$ & $\begin{array}{r}27 \\
7 \\
8 \\
6\end{array}$ \\
\hline
\end{tabular}

* Target blood pressure $=95 \mathrm{~mm} \mathrm{Hg}$ diastol ic

+ Excludes two patients (one from each group) who were delivered at other hospitals and two patients (one in each group) aborted. + Early entry = less than or equal to 32 weeks' gestation; late entry = more than 32 weeks' gestation.

Significantly more patients taking oxprenolol required additional hydralazine treatment than did those taking methyldopa $(p<0.05)$

TABLE IV-Characteristics of pregnancy in patients treated with methyldopa and oxprenolol

\begin{tabular}{|c|c|c|c|c|c|c|}
\hline & \multicolumn{2}{|c|}{ Early entry* } & \multicolumn{2}{|c|}{ Late entry* } & \multicolumn{2}{|c|}{ All patients } \\
\hline & $\begin{array}{l}\text { Methyldopa } \\
\quad(\mathrm{n}=22)\end{array}$ & $\begin{array}{l}\text { Oxprenolol } \\
(\mathbf{n}=24)\end{array}$ & $\begin{array}{l}\text { Methyldopa } \\
(n=28)\end{array}$ & $\begin{array}{l}\text { Oxprenolol } \\
(\mathrm{n}=26)\end{array}$ & $\begin{array}{l}\text { Methyldopa } \\
(n=50)\end{array}$ & $\begin{array}{l}\text { Oxprenolol } \\
(n=50)\end{array}$ \\
\hline $\begin{array}{l}\text { No admitted to hospital for hypertension } \dagger \\
\text { Median No of days in hospital }+\ddagger \\
\text { No of inpatients with abnormal antenatal }\end{array}$ & $\begin{array}{l}11 \\
14\end{array}$ & $\begin{array}{r}14 \\
7\end{array}$ & $\begin{array}{l}25 \\
14\end{array}$ & $\begin{array}{l}25 \\
14\end{array}$ & $\begin{array}{l}36 \\
15\end{array}$ & 39 \\
\hline $\begin{array}{l}\text { cardiotocogramt } \\
\text { Uric acid (mean SD): }\end{array}$ & 0 & 1 & 0 & 1 & 0 & 2 \\
\hline $\begin{array}{l}\text { At entry } \\
\text { Meant } \\
\text { Final } \dagger\end{array}$ & $\begin{array}{l}0.25(0.06) \\
0.28(0.07) \\
0.29(0.09)\end{array}$ & $\begin{array}{l}0.25(0.07) \\
0 \cdot 27(0.08) \\
0.29(0.08)\end{array}$ & $\begin{array}{l}0.34(0.07) \\
0.36(0.06) \\
0.37(0.05)\end{array}$ & $\begin{array}{l}0.34(0 \cdot 10) \\
0 \cdot 34(0 \cdot 10) \\
0 \cdot 39(0 \cdot 10)\end{array}$ & $\begin{array}{l}0.29(0.08) \\
0 \cdot 32(0 \cdot 08) \\
0.31(0.08)\end{array}$ & $\begin{array}{l}0.29(0.10) \\
0.31(0 \cdot 10) \\
0.33(0.10)\end{array}$ \\
\hline $\begin{array}{l}\text { Albuminuria: } \S \\
\text { At entry } \\
\text { Throughout } \dagger \text { study }\end{array}$ & $\begin{array}{l}1 \\
2\end{array}$ & $\begin{array}{l}1 \\
2\end{array}$ & $\mathbf{1}$ & $\frac{1}{5}$ & $\mathbf{2}$ & $\begin{array}{l}\mathbf{2} \\
\mathbf{7}\end{array}$ \\
\hline
\end{tabular}

* Early entry = less than or equal to 32 weeks' gestation; late entry = more than 32 weeks' gestation.

+ Excludes data for two patients delivered at other hospitals.

Median used because of skewed distribution of data.

More than a trace by Albustix.

TABLE V-Fetal outcome and perinatal characteristics for patients treated with methyldopa and oxprenolol and for controls

\begin{tabular}{|c|c|c|c|c|c|c|c|c|c|}
\hline & \multicolumn{3}{|c|}{ Early entry* } & \multicolumn{3}{|c|}{ Late entry* } & \multicolumn{3}{|c|}{ All patients } \\
\hline & $\begin{array}{l}\text { Methyldopa } \\
(\mathrm{n}=22)\end{array}$ & $\begin{array}{c}\text { Oxprenolol } \\
(n=24)\end{array}$ & $\begin{array}{l}\text { Controls } \\
(n=42)\end{array}$ & $\begin{array}{c}\text { Methyldopa } \\
(n=28)\end{array}$ & $\begin{array}{c}\text { Oxprenolol } \\
(n=26)\end{array}$ & $\begin{array}{l}\text { Controls } \\
(n=54)\end{array}$ & $\begin{array}{c}\text { Methyldopa } \\
(n=50)\end{array}$ & $\begin{array}{c}\text { Oxprenolol } \\
(n=50)\end{array}$ & $\begin{array}{l}\text { Controls } \\
(n=96)\end{array}$ \\
\hline Gestation at delivery (weeks) & $37 \cdot 7(2 \cdot 3)$ & $37 \cdot 1(3 \cdot 4)$ & $37 \cdot 4(2 \cdot 9)$ & $38 \cdot 3(1 \cdot 2)$ & $38 \cdot 7(1 \cdot 7)$ & $38 \cdot 4(1 \cdot 4)$ & $38 \cdot 0(1 \cdot 8)$ & $37 \cdot 9(2 \cdot 7)$ & $37 \cdot 9(2 \cdot 2)$ \\
\hline $\begin{array}{l}\text { No of live births } \\
\text { No of stillbirths } \\
\text { No of abortions }\end{array}$ & $\begin{array}{r}21 \\
0 \\
1\end{array}$ & $\begin{array}{r}23 \\
0 \\
1\end{array}$ & $\begin{array}{r}42 \\
0 \\
0\end{array}$ & $\begin{array}{r}28 \\
0 \\
-\end{array}$ & $\begin{array}{r}26 \\
0 \\
-\end{array}$ & $\begin{array}{r}52 \\
2 \\
-\end{array}$ & $\begin{array}{r}49 \\
0 \\
1\end{array}$ & $\begin{array}{r}49 \\
0 \\
1\end{array}$ & $\begin{array}{r}94 \\
2 \\
0\end{array}$ \\
\hline $\begin{array}{l}\text { Delivery: } \\
\text { Spontaneous (No) } \\
\text { Induction (No) } \\
\text { Elective caesarean section (No) } \\
\text { Abnormal cardiotocogram in }\end{array}$ & $\begin{array}{l}6 \\
6 \\
9\end{array}$ & $\begin{array}{r}4 \\
12 \\
7\end{array}$ & $\begin{array}{r}30 \\
5 \\
7\end{array}$ & $\begin{array}{r}5 \\
16 \\
7\end{array}$ & $\begin{array}{r}4 \\
18 \\
4\end{array}$ & $\begin{array}{r}43 \\
1 \\
8\end{array}$ & $\begin{array}{l}11 \\
22 \\
16\end{array}$ & $\begin{array}{r}8 \\
30 \\
11\end{array}$ & $\begin{array}{r}73 \\
6 \\
15\end{array}$ \\
\hline $\begin{array}{l}\text { labour (No)† } \\
\text { Apgar score } 7-10 \text { at } 5 \text { minutes } \\
\text { Birth weight }(\mathrm{g}) \\
\text { Adjusted birth weight (g) } \\
\text { Centile birth weight } \ddagger \\
\text { Standard deviation score of birth weight } \S \\
\text { Head circumference }(\mathrm{cm}) \\
\text { Placental weight }(\mathrm{g})\end{array}$ & $\begin{array}{c}4 \\
20 \\
2992(732) \\
2878(669) \\
104(25) \\
0 \cdot 26(1 \cdot 6) \\
34 \cdot 9(5 \cdot 1) \\
587(154)\end{array}$ & $\begin{array}{c}12 \\
21 \\
2715(919) \\
2573(879) \\
100(24) \\
0 \cdot 03(1 \cdot 4) \\
33 \cdot 4(3 \cdot 0) \\
522(158)\end{array}$ & $\begin{array}{c}9 \\
40 \\
3021(672) \\
2923(699) \\
103(16) \\
0 \cdot 22(1 \cdot 0) \\
34 \cdot 0(2 \cdot 2) \\
605(153)\end{array}$ & $\begin{array}{c}11 \\
28 \\
3020(658) \\
2902(650) \\
100(21) \\
0 \cdot 00(1 \cdot 5) \\
34 \cdot 1(1 \cdot 8) \\
566(143)\end{array}$ & $\begin{array}{c}11 \\
26 \\
3097(672) \\
2984(631) \\
100(22) \\
0 \cdot 00(1 \cdot 4) \\
34 \cdot 0(1 \cdot 8) \\
585(118)\end{array}$ & $\begin{array}{c}20 \\
51 \\
3113(506) \\
3037(527) \\
99(15) \\
-0 \cdot 08(1 \cdot 1) \\
34 \cdot 2(1 \cdot 3) \\
577(117)\end{array}$ & $\begin{array}{c}15 \\
48 \\
3009(682) \\
2892(651) \\
102(23) \\
0 \cdot 11(1 \cdot 5) \\
34 \cdot 4(3 \cdot 6) \\
576(147)\end{array}$ & $\begin{array}{c}24 \\
48 \\
2920(809) \\
2795(775) \\
100(23) \\
0 \cdot 01(1 \cdot 4) \\
33 \cdot 7(2 \cdot 4) \\
555(141)\end{array}$ & $\begin{array}{l}29 \\
91 \\
3073(583) \\
2988(607) \\
101(15) \\
0 \cdot 05(1 \cdot 1) \\
34 \cdot 1(1 \cdot 3) \\
589(134)\end{array}$ \\
\hline
\end{tabular}

* Early entry = less than or equal to 32 weeks' gestation; late entry = more than 32 weeks' gestation.

$\dagger$ Excludes data for two patients delivered at other hospitals.

† Centile birth weight $=($ birth weight $\div$ expected birth weight $) \times 100$ 
entered in both studies was fairly small. Even though our series of 100 patients was larger, we would expect to demonstrate a significant difference at the 0.05 level on $95 \%$ of occasions only if the true difference was about $550 \mathrm{~g}$ and the standard deviation of the birth weight was $750 \mathrm{~g}$. If the true difference was $400 \mathrm{~g}$, as observed by Gallery et al, we would show a significant difference at the 0.05 level on $75 \%$ of occasions.

There may be another explanation for the difference, however. It would appear that the infants of mothers treated with methyldopa in Gallery's study were abnormally small, rather than that the mothers treated with oxprenolol produced particularly large infants. There have been four reasonably large trials of antihypertensive drugs in pregnancy from Oxford (208 patients, early entry), ${ }^{8}$ Sydney (53 patients), ${ }^{4}$ Glasgow (120 patients), ${ }^{3}$ and this study. In the Oxford study methyldopa was compared with placebo; in the Sydney study methyldopa was compared with oxprenolol; and in the Glasgow study atenolol was compared with placebo. In all the studies the patients were delivered between 37.5 and 39.1 weeks; the mean birth weight in each group in all studies varied from $2920 \mathrm{~g}$ (for patients in our study treated with oxprenolol) to $3130 \mathrm{~g}$ (controls in the Oxford study $^{8}$ ) except those treated with methyldopa in the Sydney study, who were delivered at 38 weeks and whose babies weighed 2654 g. ${ }^{4}$ To make detailed comparisons between different populations is open to criticism, but one reason for this apparent discrepancy may be that in the Sydney series the maternal blood pressure of those treated with methyldopa was about $115 / 70 \mathrm{~mm} \mathrm{Hg}$, considerably lower than that in any of the other series, including ours, where the corresponding blood pressure was $132 / 88 \mathrm{~mm} \mathrm{Hg}$. Furthermore, in the Sydney study some mothers must have had blood pressures lower than the mean of $115 / 70 \mathrm{~mm} \mathrm{Hg}$ and this relatively low blood pressure may have impaired placental blood flow in a circulation that would already have been compromised and thus caused growth retardation.

Methyldopa and oxprenolol reduced diastolic blood pressure to the same extent in our study. Only 15 of the 24 patients receiving oxprenolol in the early entry group achieved target blood pressure on single or double dose of the drug and six required added hydralazine. In contrast, 20 of the 22 patients treated with methyldopa in this group achieved target blood pressure on the single or double dose and none required added hydralazine. We therefore believe that methyldopa was more effective than oxprenolol in controlling blood pressure, and this may have accounted for the pronounced difference in blood pressure between the treatment groups in the Sydney study.

The gestation at delivery, the fetal outcome, the Apgar scores at 1 and 5 minutes, and the head circumferences were comparable in all the groups studied. Because there has been concern that methyldopa may reduce brain growth in the fetus where treatment was started between 16 and 20 weeks' gestation, ${ }^{9}$ we analysed head circumferences in this group separately. There was no significant difference in mean head circumferences between these and any of the other subgroups, including g controls.

It has been suggested that the administration of beta $\frac{3}{D}$ adrenergic blockers to pregnant women is associated with fetal $\stackrel{\varrho}{c}$ bradycardia. Antenatal cardiotocography showed no excess $\widehat{C}$ prevalence of bradycardia in the patients treated with oxprenolol $\frac{\widehat{O}}{\bar{J}}$ in our study. Although the prevalence of bradycardia in labour in patients in the early entry groups who were treated with $\mathbb{D}$ oxprenolol was more than three times that of those treated with methyldopa $\left(43^{\%}, v 14_{\%}^{\circ}\right)$, the difference was not significant. The prevalence of bradycardia in the control group was $22 \%$, again $\overrightarrow{\vec{B}}$ not significantly different from that of the patients treated with $\stackrel{0}{+}$ oxprenolol. Despite the lack of statistical significance, there was a suggestion that oxprenolol caused bradycardia, and, in a larger $\frac{\overline{0}}{\overline{0}}$ study, this might prove significant. The higher incidence of $\frac{\mathrm{O}}{\vec{\sigma}}$ abnormal cardiotocograms in labour in the patients treated with $\varrho$ oxprenolol was not reflected in any increased neonatal morbidity. ڤ

In our controlled randomised study comparing methyldopa $\vec{\circ}$ with oxprenolol in the treatment of mild to moderate hypertension in pregnancy we found no significant differences in $\vec{\omega}$ final fetal outcome. This supports the findings of two other controlled studies of beta adrenergic blocking drugs in preg- $\frac{3}{3}$ nancy. ${ }^{3}{ }^{4}$ Methyldopa may be superior to oxprenolol in control of blood pressure in those presenting early in pregnancy.

We thank Mrs Alison Bisset and Susan Cowley for help in preparing the manuscript; Merck, Sharp and Dohme Limited and Ciba Labora- ! tories for support; and the consultant obstetricians at Queen Char- $\overrightarrow{0}$ lotte's Maternity Hospital for referring patients to us.

\section{References}

1 Chamberlain GVP, Lewis PJ, de Swiet M, Bulpitt CJ. How obstetricians manage hypertension in pregnancy. Br Med f 1978;i:626-9.

${ }^{2}$ Rubin PC. Current concepts: beta-blockers in pregnancy. N Engl F Med 1981 ;305:1323-6.

${ }^{3}$ Rubin PC, Clark DM, Summer DJ, Low RA, Butters L, Reynolds B. O Placebo-controlled trial of atenolol in treatment of pregnancy-associated hypertension. Lancet 1983;i:431-4.

- Gallery EDM, Saunders DM, Hunyor SN, Györy AZ. Randomised ญे comparison of methyldopa and oxprenolol for treatment of hypertension $\frac{\mathrm{O}}{\mathbb{D}}$ in pregnancy. $\mathrm{Br}$ Med $\mathcal{F} 1979 ; \mathrm{i}: 1591-4$.

5 Wright BM, Dore CF. A random zero sphygmomanometer. Lancet 1970; $\overrightarrow{\hat{\sigma}}$ i:337-8.

6 Thomson AM, Billewicz WZ, Hytten FE. The weight of the placenta in relation to birthweight. Fournal of Obstetrics and Gynaecology of the British Commonwealth 1969;76:865-72.

7 Altman DG, Coles EC. Assessing birthweight-for-dates on a continuous scale. Ann Hum Biol 1980;7:35-44.

${ }^{8}$ Redman CWG, Beilin LJ, Bonnar J, Ounsted MK. Fetal outcome in trial of antihypertensive treatment in pregnancy. Lancet 1976;ii:753-6.

${ }^{9}$ Redman CWG, Ounsted MK. Safety for the child of drug treatment for 3 hypertension in pregnancy. Lancet $1981 ; \mathrm{i}: 1237$.

(Accepted 7 April 1983)
STRAWBERRIES flower in May ordinarily, and the fruit is ripe shortly after.

Venus owns the herb. Strawberries, when they are green, are cool and dry; but when they are ripe, they are cool and moist: The berries are excellently good to cool the liver, the blood, and the spleen, or an hot choleric stomach; to refresh and comfort the fainting spirits, and quench thirst: They are good also for other inflammations; yet it is not amiss to refrain from them in a fever, lest by their putrifying in the stomach they increase the fits. The leaves and roots boiled in wine and water, and drank, do likewise cool the liver and blood, and assuage all inflammations in the reins and bladder, provoke urine, and allay the heat and sharpness thereof. The same also being drank stays the bloody flux and women's courses, and helps the swelling of the spleen. The water of the Berries carefully distilled, is a sovereign remedy and cordial in the panting and beating of the heart, and is good for the yellow jaundice. The juice dropped into foul ulcers, or they washed therewith, or the decoction of the herb and root, doth wonderfully cleanse and help to cure them. Lotions and gargles for sore mouths, or ulcers therein, or in the privy parts or elsewhere, are made $\bar{N}$ with the leaves and roots thereof; which is also good to fasten loose N teeth, and to heal spungy foul gums. It helps also to stay catarrhs, or $\sigma$ defluctions of rheum in the mouth, throat, teeth, or eyes. The juice or water is singularly good for hot and red inflamed eyes, if dropped into

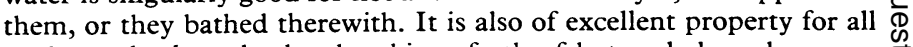
pushes, wheals and other breakings forth of hot and sharp humours in the face and hands, and other parts of the body, to bathe them $T$ therewith, and to take away any redness in the face, or spots, or other deformities in the skin, and to make it clear and smooth. Some use this medicine, Take so many Strawberries as you shall think fitting, $\frac{\mathbb{\mathbb { Q }}}{\mathbb{Q}}$ and put them into a distillatory, or body of glass fit for them, which being well closed, set it in a bed of horse dung for your use. It is an excellent water for hot inflamed eyes, and to take away a film or skin o than begins to grow over them, and for such other defects in them as may be helped by any outward medicine. (Nicholas Culpeper (161654) The Complete Herbal, 1850.) 